Tersedia online di: http://ejournal-balitbang.kkp.go.id/index.php/JP
e-mail:jurnalpari@gmail.com
JURNAL PARI
Volume 3 Nomor 1 Juli 2017
p-ISSN: 2502-0730
e-ISSN : 2549-0133

\title{
KAJI ULANG TERHADAP DOKUMEN SISTEM PENYELENGGARAAN PERPUSTAKAAN (PROSEDUR, INSTRUKSI KERJA, DAN FORMULIR) VERSI ACUAN SNI 7496 : 2009 YANG DISESUAIKAN DENGAN PEDOMAN KNAPPP 02 : 2017
}

Review of the system documents (procedures, work instruction, and forms) regulation of SNI 7496:2009 version that is adjusted to the KNAPP guide 02:2007

\section{YENI PEBRIANTI}

Balai Riset Perikanan Budidaya Air Tawar dan Penyuluhan Perikanan

Diterima tanggal : 6 Maret 2017 diterima setelah perbaikan : 24 April 2017 disetujui terbit : 14 Juni 2017

\begin{abstract}
ABSTRAK
Manajemen mutu sebuah perpustakaan yang sebelumnya telah diimplementasikan dengan acuan SNI 7496 : 2009 masih butuh kajian lanjutan guna menjadikan penyelenggaraan perpustakaan lebih baik. Kajian yang dilakukan secara deskriptif menggunakan pedoman KNAPPP 02 : 2017 menjadikan perpustakaan didukung oleh prosedur, instruksi kerja, serta formulir-formulir pendukung lainnya. Kajian ini bertujuan untuk memperbaiki dokumen sistem yang sudah ada dengan dokumen yang dipersyaratkan dalam klosul pedoman KNAPPP di atas. Hal ini dimaksudkan agar kegiatan penyelenggaraan perpustakaan secara keseluruhan dapat terekam dengan baik.
\end{abstract}

Kata Kunci : prosedur, instruksi kerja, formulir, acuan SNI 7496 : 2009, pedoman KNAPPP 02 : 2017

\section{ABSTRACT}

The library quality management which implemented must be suported accordance with SNI 7496 : 2009 still need special study to realize library's activities better. The study done descriptively accordance with the rule of KNAPPP 02 : 2017 supported by system documents includes : Standard Operating Procedures, work instruction, and forms. The aim of this study is to perfect the last system documents and replaced with the rule of KNAPPP $02: 2017$ above. Beside that, the aim of this study is to ensure that the whole activities are well documented perfectly.

Keywords: Standard Operating Procedures, work instructions, Forms, SNI 7496 : 2009, Rules of KNAPPP 02: 2017

\footnotetext{
Korespondensi penulis:

Jalan Sempur No. 1 Bogor 16129

Telp. (0251) 8313200, Fax. (0251) 8327890

Korespondensi: febrianti16@yahoo.com
} 


\section{PENDAHULUAN}

Perpustakaan Balai Riset Perikanan Budidaya Air Tawar dan Penyuluhan Perikanan merupakan perpustakaan khusus instansi pemerintah di bidang perikanan air tawar yang berada di bawah naungan instansi induknya. Perpustakaan Balai Riset Perikanan Budidaya Air Tawar dan Penyuluhan Perikanan memiliki misi menyediakan, mengolah, menyimpan serta menyebarluaskan informasi bagi pengguna perpustakaan.

Mengacu pada misi serta peranan penting dari perpustakaan BRPBATPP, maka perlu adanya suatu manajemen yang tepat sehingga fungsi perpustakaan terwujud secara optimal. Sebuah perpustakaan dikategorikan sebagai perpustakaan yang baik apabila manajemennya sudah sesuai dengan standar mutu yang ditetapkan.

Perpustakaan Balai Riset Perikanan Budidaya Air Tawar dan Penyuluhan Perikanan dalam penyelenggaraannya telah mengimplementasikan dokumen sistem perpustakaan sesuai dengan Acuan SNI 7496 : 2009 yaitu acuan bagi Perpustakaan Khusus Instansi Pemerintah. Dokumen sistem yang dimaksud terdiri dari prosedur serta formulir yang diaplikasikan pada setiap kegiatan penyelenggaraan perpustakaan.

Mengingat perpustakaan Balai Riset Perikanan Budidaya Air Tawar dan Penyuluhan Perikanan merupakan perpustakaan khusus yang berada di bawah institusi penelitian/riset, maka merupakan hal yang sangat penting bagi perpustakaan untuk dapat terintegrasi dengan pelaksanaan pranata penelitian dan pengembangan (litbang). Kinerja pranata litbang sendiri dibina oleh Menteri Negara Riset dan Teknologi melalui pembentukan Komisi Nasional Akreditasi Pranata Penelitian dan Pengembangan (KNAPPP) yang memiliki pedoman tersendiri, yaitu Pedoman KNAPPP 02 : 2017. Dengan demikian, dokumen sistem yang selama ini telah diimplementasikan perlu direvisi (dikaji ulang) dengan cara dilakukan observasi secara langsung, sinkronisasi prosedur, penambahan instruksi kerja, serta sinkronisasi formulir.

\section{Latar Belakang Masalah}

Permasalahan yang dihadapi dalam manajemen sebuah perpustakaan seringkali terletak pada dokumen pendukung kegiatan perpustakaan tersebut. Pengelola perpustakaan baik pustakawan maupun tenaga teknis telah melaksanakan kegiatan rutin (pengelolaan dan pelayanan) namun kegiatan-kegiatan tersebut tidak tercatat atau terekam dengan dengan baik sehingga pada saat ada pihak yang bertanya mengenai kegiatan apa saja yang telah dilakukan atau data mengenai kegiatan perpustakaan, pengelola perpustakaan kesulitan untuk menunjukkan bukti kegiatan yang telah dilakukannya. Maka dari itu, pada tulisan sebelumnya, penulis telah menyampaikan pengertian dari prosedur, formulir, serta bagaimana menyusun sebuah dokumen sistem sesuai klausul acuan SNI $7496: 2009$.

Setelah dokumen sistem tersusun dan mulai diaplikasikan dalam kegiatan rutin perpustakaan, dokumen sistem tersebut masih harus diperbaiki dan disesuaikan dengan pedoman KNAPPP 02: 2017. Permasalahan selanjutnya yang dihadapi adalah bagaimana proses mengintegrasikan/ sinkronisasi antara dokumen sistem yang sudah tersusun berdasarkan acuan SNI 7496: 2009 untuk disempurnakan sesuai dengan pedoman KNAPPP 02 : 2017 yang baru diterbitkan pada tanggal 6 Maret 2017.

\section{Rumusan Masalah}

Dampak yang ditimbulkan oleh permasalahan tersebut di atas adalah dibutuhkan penambahan instruksi kerja yang dapat menjelaskan langkahlangkah atau urutan prosedur pekerjaan secara terperinci. Selain itu, perlu sinkronisasi antara prosedur serta formulir yang sudah terlebih dahulu disusun.

\section{Tujuan Pengkajian}

Dengan adanya latar belakang permasalahan di atas, maka dibutuhkan kajian lebih lanjut mengenai formulasi dokumen sistem sehingga menjadi sempurna dan lebih mempermudah penyelenggaraan perpustakaan.

\section{Manfaat Pengkajian}

Dengan adanya kajian lanjutan ini, penyelenggaraan perpustakaan akan mudah dilaksanakan, informasi dan data mudah tertelusur, serta pelayanan perpustakaan akan menjadi lebih baik.

\section{TINJAUAN PUSTAKA}

Menurut wikipedia, dokumen adalah sebuah tulisan yang memuat informasi. Biasanya, dokumen ditulis di kertas dan informasinya ditulis memakai 
tinta baik memakai tangan atau memakai media elektronik.

Sedangkan berdasarkan Kamus Besar Bahasa Indonesia (KBBI), dokumen diartikan sebagai 1. surat yang tertulis atau tercetak yang dapat dipakai sebagai bukti keterangan (seperti akta kelahiran, surat nikah, surat perjanjian), 2. barang cetakan atau naskah karangan yang dikirim melalui pos, 3 . rekaman suara, gambar dalam film, dan sebagainya yang dapat dijadikan bukti keterangan.

Dokumen adalah segala benda yang berbentuk barang, gambar, ataupun tulisan sebagai bukti dan dapat memberikan keterangan yang penting dan absah. Dokumen perpustakaan dikompilasi dengan proses dokumentasi dengan tujuan sebagai sarana komunikasi.

Sistem adalah suatu jaringan kerja dari prosedur-prosedur yang saling berhubungan, berkumpul bersama-sama untuk melakukan suatu kegiatan atau untuk menyelesaikan suatu sasaran tertentu.

Dokumen sistem yang dimaksud dalam tulisan ini adalah kumpulan beberapa dokumen yang berisi mengenai rekaman kegiatan selama pengelolaan perpustakaan berlangsung. Dokumen sistem terdiri dari prosedur, instruksi kerja, serta formulir-formulir terkait penyelenggaraan perpustakaan.

Dokumen pertama dari dokumen sistem adalah prosedur yang digunakan untuk menilai apakah kegiatan sudah dilakukan dengan baik atau tidak. Prosedur dibuat dengan tujuan sebagai berikut :

1. Agar pengelola perpustakaan mampu menjaga konsistensi dan tingkat kinerja pengelola perpustakaan dalam organisasi atau unit kerja.

2. Agar mengetahui dengan jelas peran dan fungsi tiap-tiap posisi dalam organisasi.

3. Memperjelas alur tugas, wewenang dan tanggung jawab dari pengelola perpustakaan terkait.

Fungsi dari Standar Operasional Prosedur (SOP) adalah sebagai berikut :

1. Memperlancar tugas dari pengelola perpustakaan.

2. Mengetahui dengan jelas hambatan-hambatan yang dihadapi dan mudah dilacak.

3. Mengarahkan pengelola perpustakaan untuk disiplin dalam bekerja.

4. Sebagai pedoman dalam melaksanakan kegiatan rutin.
Dokumen kedua dari dokumen sistem adalah instruksi kerja adalah dokumen mekanisme kerja yang mengatur secara rinci dan jelas urutan suatu aktifitas yang hanya melibatkan satu fungsi saja sebagai pendukung prosedur. Prinsip instruksi kerja menguraikan bagaimana satu langkah dalam suatu prosedur dilakukan. Terkadang penulisan prosedur sangat panjang sehingga tidak rinci penguraiannya sehingga memerlukan penjelasan yang lebih detail dan rinci dengan menggunakan instruksi kerja.

Dokumen ketiga dari dokumen sistem adalah formulir yang menjadi pendukung instruksi kerja yang telah dibuat. Formulir didefinisikan sebagai lembaran kartu/kertas dengan ukuran tertentu yang didalamnya terdapat data/informasi yang bersifat tetap dan juga bagian lain yang diisi dengan bagian yang tidak tetap. Manfaat dengan adanya formulir adalah dapat menetapkan tanggung jawab terjadinya transaksi (bisnis), merekam data transaksi, mengurangi kesalahan pesan dibanding dengan cara lisan, serta dapat menjadi media komunikasi antar orang/bagian/organisasi. Formulir yang telah diisi menjadi rekaman dan merupakan bukti bahwa suatu kegiatan telah dilakukan dan sistem mutu telah diterapkan secara efektif.

Komisi Nasional Akreditasi Pranata Penelitian dan Pengembangan (KNAPPP) dibentuk dengan tujuan untuk mengembangkan dan memberikan saran kepada Menteri Negara Riset dan Teknologi perihal sistem akreditasi Pranata penelitian dan pengembangan. Akreditasi diberikan kepada Pranata Litbang milik pemerintah maupun swasta yang telah memenuhi persyaratan akreditasi Pranata Litbang. Dengan demikian, kinerja Pranata Litbang diharapkan dapat meningkatkan mutu dan efektivitasnya. Dalam pelaksanaan akreditasi Pranata Litbang, KNAPPP telah menerbitkan Pedoman KNAPPP yang terdiri dari unsur-unsur persyaratan yaitu sebagai berikut : 1) organisasi dan lingkup kegiatan, 2) kepemimpinan, 3) strategi organisasi, 4) pengukuran kinerja, 5) proses dan manajemen, 6) manajemen kekayaan intelektual dan hasil, 7) manajemen pelanggan dan pemangku kepentingan, dan 8) manajemen kompetensi.

Organisasi dan Lingkup Kegiatan menjelaskan bahwa Pranata Litbang merupakan organisasi yang kegiatan intinya adalah penelitian dan pengembangan, baik yang memiliki landasan hukum sendiri maupun yang merupakan unit kerja dari organisasi yang memiliki landasan hukum yang 
telah ditetapkan. Pranata litbang harus mempunyai Manajer Puncak yang dibantu oleh Manajer Mutu dan Manajer Teknis. Lingkup kegiatan pranata litbang harus selaras dan dapat diperluas sesuai dengan peningkatan sumber daya yang dimiliki. Manajemen Puncak harus menetapkan visi, misi, kebijakan dan sasaran Pranata Litbang yang didukung rencana strategis serta pengembangan kemitraan. Pranata Litbang harus menetapkan, melaksanakan dan memelihara prosedur untuk mengukur dan menganalisis kinerja organisasi melalui Tinjauan Kinerja Internal minimal satu tahun sekali.

Terkait dengan proses dan manajemen, kode etik pranata litbang, identifikasi potensi risiko yang mungkin terjadi dan menganalisis risiko untuk melakukan tindakan pencegahan, mengurangi atau menghilangkan risiko harus ditetapkan. Pelaksanaan audit internal serta kaji ulang manajemen dilakukan minimal satu tahun sekali.

Pada poin manajemen kekayaan intelektual dan hasil, Pranata Litbang harus menetapkan, menerapkan dan memelihara prosedur yang terkait dengan pengelolaan, perlindungan dan diseminasi hasil penelitian dan pengembangan termasuk kekayaan intelektual yang digunakan oleh pihak lain, atau kekayaan intelektual pihak lain yang digunakan oleh Pranata Litbang. kekayaan intelektual yang dimaksud adalah yang bersifat "codified" (paten, merek, hak cipta, desain industri, desain tata letak sirkuit terpadu, perlindungan varietas tanaman dan rahasia dagang) maupun yang bersifat "tacit".

Manajemen Pelanggan dan Pemangku Kepentingan menjelaskan bahwa Pranata Litbang harus memiliki kebijakan dan prosedur yang terkait dengan : a) Penetapan tingkat pelayanan (service level agreement) terhadap pelanggan dan pemangku kepentingan; b) Kerahasiaan yang berkaitan dengan kepentingan pengguna jasa penelitian dan pengembangan; c) Penanganan keluhan. Sedangkan Manajemen Kompetensi menjelaskan Pranata Litbang harus memiliki kebijakan dan prosedur untuk: a) Rekruitmen, pemeliharaan dan pengembangan kompetensi tenaga penelitian dan pengembangan; b) Pemeliharaan dan pengembangan sarana dan prasarana penelitian dan pengembangan; c) Pemilihan sumber daya eksternal guna menunjang kegiatan penelitian dan pengembangan.

\section{Metode Pengkajian}

Metode yang digunakan dalam penulisan ini adalah metode deskriptif dimana tulisan merupakan hasil dari kajian terhadap apa yang terjadi di perpustakaan Balai penelitian dan Pengembangan Budidaya Air Tawar dengan tujuan menggambarkan situasi serta fakta yang ada. Metode dilakukan dengan cara observasi serta evaluasi langsung terhadap pengaplikasian dokumen sistem yang sudah ada dan terjadi di perpustakaan Balai Riset Perikanan Budidaya Air Tawar dan Penyuluhan Perikanan.

\section{Teknik Analisis Data}

Teknik dalam mengumpulkan data dilakukan dengan cara mengobservasi secara langsung dan evaluasi terhadap kegiatan rutin yang dilakukan di perpustakaan Balai Riset Perikanan Budidaya Air Tawar dan Penyuluhan Perikanan. Mengobservasi serta mengevaluasi dilaksanakan dengan cara mengetahui sejauhmana dokumen sistem dapat secara efektif diaplikasikan serta melakukan penyempurnaan terhadap dokumen sistem yang sudah ada.

\section{HASIL DAN PEMBAHASAN}

Berdasarkan kajian yang dilakukan penulis terhadap apa yang telah dilakukan, tentu sangatlah penting sebuah perpustakaan untuk memiliki dokumen sistem pendukung penyelenggaraan perpustakaan. Berdasarkan acuan SNI 7496 : 2009, dokumen sistem yang berlaku di perpustakaan terdiri dari 1 panduan, 18 prosedur (SOP), serta 35 formulir tanpa instruksi kerja. Sedangkan berdasarkan pedoman KNAPPP serta unsur-unsur di dalamnya, terdapat pernyataan pada poin 5.9 yaitu "Pranata Litbang perlu mempunyai sumber daya informasi yang dapat menunjang pelaksanaan kegiatan penelitian dan pengembangan, tapi tidak terbatas pada hal-hal berikut: a) Perpustakaan; b) Laman; c) Basis data hasil penelitian dan pengembangan". Melalui pernyataan tersebut, maka dapat diperoleh kode prosedur penyelenggaraan perpustakaan adalah 5.9 dan mengakibatkan terjadi perubahan pada dokumen sistem yang sebelumnya telah tersusun dan perubahan ini menjadikan dokumen sistem lebih sempurna.

Panduan yang sebelumnya dibuat sesuai SNI 7496 : 2009 mencakup ruang lingkup, istilah dan 
definisi, misi, tugas, fungsi, koleksi, pengorganisasian materi perpustakaan, sumber daya manusia, manajemen, layanan perpustakaan, organisasi perpustakaan, gedung, anggaran, serta teknologi informasi dan komunikasi.

Dengan adanya perubahan ini, panduan tidak lagi disusun oleh perpustakaan melainkan disusun oleh tim Balai yang akan menjadi panduan mutu poin layanan secara keseluruhan Balai. Prosedur tetap disusun yang dilengkapi dengan instruksi kerja dan didukung dengan adanya formulir terkait. Sehingga dari hasil kajian yang telah dilakukan penulis, dokumen sistem terdiri dari 3 (tiga) unsur utama, yaitu prosedur, instruksi kerja, dan formulir.

\section{Prosedur Penyelenggaraan Perpustakaan}

Standar Operasional Prosedur (SOP) dibuat berdasarkan acuan SNI 7496 : 2009 dan disesuaikan dengan kondisi kegiatan di perpustakaan Balai Penelitian dan Pengembangan Budidaya Air Tawar. Standar Operasional Prosedur (SOP) terdiri dari tujuan, ruang lingkup, pustaka, prosedur dan cara pengerjaannya, dan formulir terkait dengan prosedur tersebut.

Sedangkan berdasarkan Pedoman KNAPPP 02 : 2017, Prosedur penyelenggaraan perpustakaan (PR.5.9.1) mencakup tujuan dari penyelenggaraan perpustakaan, ruang lingkup dokumen dibuat, acuan yang digunakan, penanggung jawab kegiatan, serta uraian tata cara penyelenggaraan perpustakaan, dan dokumen terkait.

Uraian tata cara dimulai dari pengelolaan, pengembangan, pengolahan, penyimpanan dan perawatan koleksi, layanan sirkulasi, layanan penelusuran informasi literatur, layanan orientasi perpustakaan, penyusunan data statistik kepustakawanan, penyusunan laporan tahunan, penyusunan Indeks Kepuasan Pemustaka (IKP), sampai pada kegiatan yang berkaitan dengan pengembangan profesi dan penunjang tugas pustakawan.

Tata cara pengelolaan perpustakaan mencakup kegiatan merencanakan penyelenggaraan perpustakaan secara spesifik, terukur, realistis, dan terjadwal di setiap awal tahun dengan menyesuaikan target SKP.

Tata cara pengembangan koleksi merupakan salah satu kegiatan layanan teknis perpustakaan yang mengatur tahapan yang harus dilakukan pada saat bahan pustaka diterima untuk pertama kalinya sebelum siap dilayankan kepada pemustaka.
Tata cara pengolahan merupakan salah satu kegiatan layanan teknis perpustakaan yang mengatur tahapan yang harus dilakukan pada saat bahan pustaka telah melalui tahap penerimaan serta registrasi.

Tata cara penyimpanan dan perawatan koleksi merupakan salah satu kegiatan layanan teknis yang harus dilakukan secara rutin dengan menyesuaikan ketentuan yang berlaku dan dapat dilakukan 2 kali dalam 1 bulan. Koleksi bahan pustaka yang mengalami kerusakan wajib didata melalui identifikasi kerusakan koleksi untuk segera dilakukan perbaikan.

Tata cara layanan sirkulasi merupakan salah satu kegiatan layanan pemustaka yang berkaitan dengan keanggotaan perpustakaan, peminjaman dan pengembalian bahan pustaka, layanan pengunjung, dan layanan fotokopi.

Tata cara layanan penelusuran informasi literatur merupakan salah satu layanan pemustaka yang memudahkan pemustaka dalam memperoleh informasi berupa literatur koleksi yang dimiliki oleh perpustakaan. Adapaun daftar topik penelusuran direkap dan disimpan sebagai bukti pelayanan.

Tata cara layanan orientasi perpustakaan merupakan salah satu layanan pemustaka yang diperuntukkan bagi siswa/i ataupun mahasiswa yang melakukan PKL, magang, penelitian di perpustakaan. Peserta orientasi perpustakaan diberikan kegiatan yang disesuaikan dengan jadwal yang telah disusun pada hari pertama kegiatan berlangsung dan sebagai bukti layanan orientasi perpustakaan telah dilaksanakan, maka peserta diwajibkan untuk membuat draft laporan yang akan dikoreksi oleh pembimbing orientasi serta mendokumentasikan kegiatan berupa foto bersama sebagai data dukung laporan orientasi.

Tata cara penyusunan data statistik kepustakawanan dilakukan dengan tujuan agar dengan mudah diketahui seberapa banyak koleksi yang dimiliki oleh perpustakaan, jumlah pengunjung, topik yang paling sering dicari oleh pemustaka, dan informasi lainnya terkait dengan kepustakawanan.

Tata cara penyusunan laporan tahunan dimaksudkan agar memudahkan dalam mengetahui kegiatan penyelenggaraan perpustakaan dalam satu tahun yang disesuaikan dengan logbook kegiatan.

Tata cara penyusunan Indeks Kepuasan Pemustaka (IKP) dimaksudkan untuk mengetahui penilaian pemustaka terhadap layanan 
perpustakaan. Indeks Kepuasan Pemustaka (IKP) diperoleh dari hasil kuesioner yang diberikan kepada pemustaka dan diolah berdasarkan rumus perhitungan.

Tata cara pengembangan profesi dan penunjang tugas pustakawan merupakan penyempurnaan sistem kepustakawanan, pengkajian, penyuluhan, sosialisasi, pameran, penyusunan karya tulis ilmiah, peran serta dalam seminar/lokakarya, keanggotaan dalam organisasi profesi, dan kegiatan lain yang berkaitan dengan pustakawan. Kegiatan yang diikuti oleh pengelola perpustakaan atau pustakawan wajib dilaporkan dan dicantumkan dalam laporan tahunan.

\section{Instruksi Kerja (Ik)}

Instruksi Kerja (IK) mencakup ruang lingkup, sarana, tahapan kegiatan, serta dokumen yang terkait dengan instruksi kerja tersebut. Setelah mengalami proses kajian, Instruksi kerja yang diterapkan di perpustakaan Balai Riset Perikanan Budidaya Air Tawar dan Penyuluhan Perikanan terdiri dari 11 instruksi kerja, yaitu sebagai berikut :

Instruksi kerja Penyusunan Rencana Operasional Kegiatan Pustakawan (ROKP) dalam rangka perencanaan penyelenggaraan kegiatan perpustakaan dilakukan dengan tahapan : Penanggung jawab kegiatan mengumpulkan dan mengolah data dukung penyusunan Rencana Operasional Kegiatan (ROK) disesuaikan dengan target dan capaian yang diperoleh tahun sebelumnya.

Instruksi kerja pengembangan koleksi dilakukan dengan tahapan : Bahan pustaka baru diterima oleh penanggung jawab kegiatan perpustakaan yang kemudian diseleksi sesuai dengan jenis bahan pustaka untuk selanjutnya dilakukan registrasi baik secara manual maupun dientri ke dalam database. Tahapan selanjutnya adalah memberikan stempel kepemilikan.

Instruksi kerja pengolahan bahan perpustakaan dilakukan dengan tahapan : mengkatalog, mengklasifikasi, sampai pada tahap melengkapi fisik bahan pustaka.

Instruksi kerja penyimpanan dan perawatan koleksi perpustakaan dilakukan dengan tahapan : persiapan perlengkapan perawatan bahan pustaka, proses perawatan (pembersihan rak koleksi, penataan ulang, pencatatan bahan pustaka) sementara koleksi yang mengalami kerusakan, harus dibuatkan berita acara yang kemudian dilaporkan kepada penanggung jawab untuk segera dilakukan tindakan.

Instruksi kerja pelaksanaan layanan sirkulasi meliputi langkah dalam keanggotaan perpustakaan yang dimulai dari pengisian formulir permohonan, validasi data, mendata, sampai pada langkah pencetakan kartu anggota perpustakaan. Selain itu, dijelaskan pula tahapan dalam proses layanan peminjaman dan pengembalian bahan pustaka yang dikhususkan bagi anggota perpustakaan. Layanan pengunjung juga harus diperhatikan, dimana setiap pengunjung yang datang ke perpustakaan diingatkan untuk selalu mencatatkan data pribadi di buku tamu sehingga hal ini akan memudahkan dalam penyusunan statistik pengunjung. Tahapan terakhir dalam layanan sirkulasi yang diberikan oleh perpustakaan adalah layanan fotocopy dimulai dari permohonan fotocopy sampai pada tahap dimana pengguna memperoleh hasil fotocopy.

Instruksikerjapelaksanaan layanan penelusuran informasi literatur dimulai dari tahap permohonan dari pengguna perpustakaan yang ditampung melalui form dan diserahkan kepada penanggung jawab kegiatan untuk selanjutnya dilakukan proses penelusuran. Tahap ini dilakukan melalui sarana database yang ada di perpustakaan dan jika literatur yang dicari sudah berhasil ditelusur, tahap selanjutnya adalah menelusur secara langsung di rak koleksi yang kemudian menyerahkan literatur tersebut kepada pengguna perpustakaan. Tahapan selalu terekam dengan cara mengisi formulir yang telah tersedia.

Instruksi kerja pelaksanaan layanan orientasi perpustakaan merupakan layanan dengan tahap awal berupa perkenalan mengenai penyelenggaraan perpustakaan, kemudian dilanjutkan dengan penyerahan jadwal kegiatan selama kegiatan orientasi berlangsung.

Instruksi kerja penyusunan data statistik kepustakawanan merupakan layanan yang dilakukan dengan tahapan merekap data kepustakawanan khususnya terkait dengan koleksi, pengunjung, topik penelusuran, layanan, dan lain sebagainya yang kemudian diolah menjadi data statistik yang bermanfaat bagi pengguna yang membutuhkan.

Instruksi kerja penyusunan laporan tahunan merupakan tahapan merekap kegiatan yang dilakukan perpustakaan dalam 1 tahun sehingga terlihat sejauhmana pencapaian perpustakaan. 
Instruksi kerja penyusunan Indeks Kepuasan Pemustaka (IKP) merupakan tahapan yang dilakukan dengan tujuan untuk mengetahui nilai indeks kepuasan pengguna perpustakaan terhadap perpustakaan (dinilai dari 14 unsur yaitu : prosedur pelayanan, persyaratan pelayanan, kejelasan petugas pelayanan, kedisiplinan petugas pelayanan, tanggung jawab petugas pelayanan, kemampuan petugas pelayanan, kecepatan pelayanan, keadilan dalam memperoleh pelayanan, kesopanan dan keramahan petugas pelayanan, kewajaran biaya pelayanan, kepastian biaya pelayanan, kepastian jadwal pelayanan, kenyamanan lingkungan, dan keamanan pelayanan). Indeks kepuasan pengguna diperoleh dari data kuesioner yang telah disebar kepada pengguna perpustakaan yang kemudian diolah dengan menggunakan rumus perhitungan IKP.

Instruksi kerja pengembangan sistem kepustakawanan, pengembangan profesi, serta penunjang tugas pustakawan merupakan tahapan kegiatan penyempurnaan sistem kepustakawanan yang meliputi pengkajian kepustakawanan, pembuatan kajian baik bersifat sederhana maupun kompleks, membuat model (prototype) perpustakaan, melakukan penterjemahan dan atau saduran, mengikuti seminar/lokakarya, membuat karya tulis ilmiah, dan kegiatan penunjang tugas pustakawan lainnya.

\section{Formulir (Fr)}

Formulir berfungsi sebagai data dukung bagi setiap prosedur dan instruksi kerja yang ada dan saling berkaitan antara satu formulir dengan formulir yang lain. Formulir yang diterapkan di perpustakaan Balai Riset Perikanan Budidaya Air Tawar dan Penyuluhan Perikanan terdiri dari 28 formulir.

\section{KESIMPULAN}

Dengan adanya kajian tentang dokumen sistem ini, diharapkan dapat membantu kelancaran kegiatan penyelenggaraan perpustakaan sehingga pelayanan perpustakaan menjadi lebih baik.

\section{SARAN}

Diharapkan Balai Riset Perikanan Budidaya Air Tawar dan Penyuluhan Perikanan dapat memberikan dukungan serta fasilitas yang dibutuhkan sehingga kelancaran penyelenggaraan perpustakaan dapat terwujud.

\section{DAFTAR PUSTAKA}

Badan Standardisasi Nasional. 2009. SNI Perpustakaan Khusus Instansi Pemerintah. Jakarta : Badan Standardisasi Nasional

Pebrianti, Yeni. Perhitungan Indeks Kepuasan Pemustaka (IKP) Terkait Upaya Peningkatan Pelayanan di Perpustakaan. Dalam Prosiding Forum Kepustakawanan Lingkup Badan Penelitian dan Pengembangan Kelautan dan Perikanan 2012. Jakarta : Balitbang KP

Perpustakaan Nasional Republik Indonesia. 2015. Peraturan Kepala Perpustakaan Nasional Republik Indonesia Nomor II Tahun 2015 tentang Petunjuk Teknis Jabatan Fungsional Pustakawan dan Angka Kreditnya. Jakarta : Perpustakaan Nasional RI

Prasetyo, Hanung Nindito. Perbedaan prosedur dan instruksi kerja (diakses Desember 2017).

\section{https://id.wikipedia.org/wiki/Dokumen}

https://id.wikipedia.org/wiki/Manajemen

http://inamayladin.blogspot.co.id/2013/11/ pengertian-dokumen-dokumentasi.html

http://knappp.ristekdikti.go.id/index.php/panduan (diakses April 2017)

http://www.dickidirmania.com/2013/05/ pengertian-sop-standar-operasional.html

http://zheefha.blogspot.co.id/2009/11/ pengelolaan-perpustakaan.html 
Lampiran : Perubahan Daftar Induk Dokumen Perpustakaan BRPBATPP

\begin{tabular}{|c|c|c|c|c|c|}
\hline \multicolumn{3}{|c|}{$\begin{array}{l}\text { Daftar Induk Dokumen } \\
\text { Sebelum dievaluasi/dikaji ulang } \\
\text { (Berdasarkan Klausul pada } \\
\text { Acuan SNI } 7496: \text { 2009) }\end{array}$} & \multicolumn{3}{|c|}{$\begin{array}{l}\text { Daftar Induk Dokumen } \\
\text { Setelah dievaluasi/dikaji ulang } \\
\text { (Berdasarkan Klausul pada } \\
\text { Pedoman KNAPPP } 02: \text { 2017) }\end{array}$} \\
\hline Prosedur & $\begin{array}{c}\text { Instruksi } \\
\text { Kerja }\end{array}$ & Formulir & $\begin{array}{l}\text { Prosedur } \\
\text { (PR) }\end{array}$ & $\begin{array}{l}\text { Instruksi Kerja } \\
\text { (IK) }\end{array}$ & $\begin{array}{c}\text { Formulir } \\
\text { (FR) }\end{array}$ \\
\hline $\begin{array}{l}\text { PR.9.1 } \\
\text { SOP } \\
\text { Perencanaan } \\
\text { Pengelolaan } \\
\text { Perpustakaan }\end{array}$ & - & $\begin{array}{l}\text { Formulir Rencana } \\
\text { Operasional Kerja } \\
\text { Pustakawan } \\
\text { (ROKP), } \\
\text { surat masuk, } \\
\text { surat keluar, } \\
\text { permohonan } \\
\text { pengadaan } \\
\text { barang }\end{array}$ & \begin{tabular}{|l|} 
PR.5.9.1 \\
Prosedur \\
Penyelenggaraan \\
Perpustakaan \\
(Pengelolaan dan \\
Pelayanan)
\end{tabular} & $\begin{array}{l}\text { IK.5.9.1.1 } \\
\text { Penyusunan } \\
\text { Rencana Operasional } \\
\text { Kegiatan Pustakawan } \\
\text { (ROKP) dalam } \\
\text { rangka perencanaan } \\
\text { penyelenggaraan } \\
\text { kegiatan perpustakaan }\end{array}$ & $\begin{array}{l}\text { FR.5.9.1.1.1 } \\
\text { Rencana Operasional } \\
\text { Kegiatan } \\
\text { FR. 5.9.1.1.2 } \\
\text { Sasaran Kerja } \\
\text { Pegawai } \\
\text { FR.5.9.1.1.3 } \\
\text { Pengumpulan dan } \\
\text { Pengolahan Data }\end{array}$ \\
\hline $\begin{array}{l}\text { PR.6.1 } \\
\text { SOP } \\
\text { Penerimaan } \\
\text { Bahan Pustaka }\end{array}$ & - & $\begin{array}{l}\text { Formulir tanda } \\
\text { terima publikasi / } \\
\text { Karya Tulis IImiah }\end{array}$ & & $\begin{array}{l}\text { IK.5.9.1.2 } \\
\text { Pengembangan } \\
\text { Koleksi }\end{array}$ & $\begin{array}{l}\text { FR. 5.9.1.2.1 } \\
\text { Tanda Terima } \\
\text { Publikasi } \\
\text { FR. 5.9.1.2.2 } \\
\text { Registrasi Bahan } \\
\text { Pustaka } \\
\text { FR. 5.9.1.2.3 Koleksi } \\
\text { Bahan Pustaka } \\
\end{array}$ \\
\hline $\begin{array}{l}\text { PR.6.3 } \\
\text { SOP } \\
\text { Penambahan } \\
\text { Koleksi Bahan } \\
\text { Pustaka }\end{array}$ & - & $\begin{array}{l}\text { Formulir buku } \\
\text { induk bahan } \\
\text { pustaka, daftar } \\
\text { bahan pustaka } \\
\text { hasil registrasi } \\
\\
\text { Formulir daftar } \\
\text { bibliografi } \\
\text { elektronis, } \\
\text { verifikasi data } \\
\text { bibliografi, } \\
\text { statistik koleksi } \\
\text { bahan pustaka, } \\
\text { kelengkapan } \\
\text { bahan pustaka, } \\
\text { kliping }\end{array}$ & & $\begin{array}{l}\text { IK. 5.9.1.3 } \\
\text { Pengolahan Bahan } \\
\text { Perpustakaan }\end{array}$ & $\begin{array}{l}\text { FR. 5.9.1.3.1 } \\
\text { Katalogisasi dan } \\
\text { Klasifikasi Bahan } \\
\text { Pustaka } \\
\text { FR. 5.9.1.3.2 } \\
\text { Daftar Bibliografi } \\
\text { FR. 5.9.1.3.3 } \\
\text { Kumpulan Abstrak } \\
\text { FR. 5.9.1.3.4 } \\
\text { Kliping Media Cetak }\end{array}$ \\
\hline $\begin{array}{l}\text { PR.7.1 } \\
\text { SOP } \\
\text { Katalogisasi } \\
\text { Bahan Pustaka }\end{array}$ & - & $\begin{array}{l}\text { Formulir } \\
\text { katalogisasi }\end{array}$ & & & \\
\hline $\begin{array}{l}\text { PR.7.2 } \\
\text { SOP Klasifikasi } \\
\text { Bahan Pustaka }\end{array}$ & 1- & Formulir klasifikasi & & & \\
\hline $\begin{array}{l}\text { PR.6.4 } \\
\text { SOP Perawatan } \\
\text { Bahan Pustaka }\end{array}$ & - & $\begin{array}{l}\text { Formulir jadwal } \\
\text { perawatan bahan } \\
\text { pustaka }\end{array}$ & & $\begin{array}{l}\text { IK. 5.9.1.4 } \\
\text { Penyimpanan dan } \\
\text { Perawatan Koleksi } \\
\text { Perpustakaan }\end{array}$ & $\begin{array}{l}\text { FR. 5.9.1.4.1 } \\
\text { Perawatan Koleksi } \\
\text { FR. 5.9.1.4.2 } \\
\text { Identifikasi } \\
\text { Kerusakan Koleksi }\end{array}$ \\
\hline
\end{tabular}




\begin{tabular}{|c|c|c|c|c|c|}
\hline \multicolumn{3}{|c|}{$\begin{array}{l}\text { Daftar Induk Dokumen } \\
\text { Sebelum dievaluasi/dikaji ulang } \\
\text { (Berdasarkan Klausul pada } \\
\text { Acuan SNI } 7496: \text { 2009) }\end{array}$} & \multicolumn{3}{|c|}{$\begin{array}{l}\text { Daftar Induk Dokumen } \\
\text { Setelah dievaluasi/dikaji ulang } \\
\text { (Berdasarkan Klausul pada } \\
\text { Pedoman KNAPPP } 02: \text { 2017) }\end{array}$} \\
\hline Prosedur & $\begin{array}{c}\text { Instruksi } \\
\text { Kerja }\end{array}$ & Formulir & $\begin{array}{c}\text { Prosedur } \\
\text { (PR) }\end{array}$ & $\begin{array}{c}\text { Instruksi Kerja } \\
\text { (IK) }\end{array}$ & $\begin{array}{c}\text { Formulir } \\
\text { (FR) }\end{array}$ \\
\hline $\begin{array}{l}\text { PR.10.1 } \\
\text { SOP Layanan } \\
\text { Bagi Pemustaka } \\
\text { PR.10.2 } \\
\text { SOP Layanan } \\
\text { Keanggotaan } \\
\text { PR.10.3 } \\
\text { SOP Layanan } \\
\text { Peminjaman } \\
\text { Bahan Pustaka } \\
\text { PR.10.4 } \\
\text { SOP Layanan } \\
\text { Pengembalian } \\
\text { Bahan Pustaka } \\
\text { PR.10.5 } \\
\text { SOP Layanan } \\
\text { Permohonan } \\
\text { Pesanan } \\
\text { Fotocopy } \\
\text { PR.10.6 } \\
\text { SOP Layanan } \\
\text { Pengambilan } \\
\text { Hasil Fotocopy }\end{array}$ & - & $\begin{array}{l}\text { Formulir tata } \\
\text { tertib, buku } \\
\text { tamu, statistik } \\
\text { pengunjung } \\
\text { Formulir } \\
\text { permohonan } \\
\text { keanggotaan } \\
\text { Formulir layanan } \\
\text { peminjaman dan } \\
\text { pengembalian } \\
\text { bahan pustaka } \\
\text { Formulir layanan } \\
\text { peminjaman dan } \\
\text { pengembalian } \\
\text { bahan pustaka } \\
\text { Formulir } \\
\text { permohonan } \\
\text { fotocopy }\end{array}$ & & $\begin{array}{l}\text { IK. 5.9.1.5 } \\
\text { Pelaksanaan Layanan } \\
\text { Sirkulasi }\end{array}$ & $\begin{array}{l}\text { FR. 5.9.1.5.1 } \\
\text { Permohonan } \\
\text { Keanggotaan } \\
\text { Perpustakaan } \\
\text { FR. 5.9.1.5.2 } \\
\text { Rekapitulasi } \\
\text { Data Anggota } \\
\text { Perpustakaan } \\
\text { FR. 5.9.1.5.3 } \\
\text { Kartu Anggota } \\
\text { Perpustakaan } \\
\text { FR. 5.9.1.5.4 } \\
\text { Layanan Peminjaman } \\
\text { Koleksi } \\
\text { FR. 5.9.1.5.5 } \\
\text { Buku Tamu } \\
\text { Pe-ngunjung } \\
\text { Perpustakaan } \\
\text { FR.5.9.1.5.6 } \\
\text { Permohonan } \\
\text { Fotocopy } \\
\text { FR.5.9.1.5.7 } \\
\text { Pengambilan Hasil } \\
\text { Fotocopy }\end{array}$ \\
\hline $\begin{array}{l}\text { PR.10.7 } \\
\text { SOP Layanan } \\
\text { Penelusuran } \\
\text { Informasi } \\
\text { Literatur }\end{array}$ & - & \begin{tabular}{|l|} 
Formulir \\
permohonan \\
penelusuran \\
informasi literatur, \\
hasil penelusuran
\end{tabular} & & $\begin{array}{l}\text { IK. 5.9.1.6 } \\
\text { Pelaksanaan Layanan } \\
\text { Penelusuran Informasi } \\
\text { Literatur }\end{array}$ & \begin{tabular}{|l|} 
FR. 5.9.1.6.1 \\
Permohonan \\
Penelusuran \\
Informasi \\
FR. 5.9.1.6.2 \\
Daftar Topik \\
Penelusuran
\end{tabular} \\
\hline $\begin{array}{l}\text { PR.10.8 } \\
\text { SOP Layanan } \\
\text { Orientasi Bagi } \\
\text { Pemustaka }\end{array}$ & - & $\begin{array}{l}\text { Formulir jadwal } \\
\text { orientasi } \\
\text { layanan, laporan } \\
\text { pembimbing } \\
\text { orientasi }\end{array}$ & & \begin{tabular}{|l} 
IK. 5.9.1.7 \\
Pelaksanaan \\
Layanan Orientasi \\
Perpustakaan
\end{tabular} & $\begin{array}{l}\text { FR. 5.9.1.7.1 } \\
\text { Jadwal Orientasi } \\
\text { Perpustakaan } \\
\text { FR. 5.9.1.7.2 } \\
\text { Laporan Orientasi } \\
\text { Perpustakaan }\end{array}$ \\
\hline & & & & \begin{tabular}{|l|} 
IK. 5.9.1.8 \\
Penyusunan \\
Data Statistik \\
Kepustakawanan
\end{tabular} & FR. 5.9.1.8.1 Statistik \\
\hline
\end{tabular}




\begin{tabular}{|c|c|c|c|c|c|}
\hline \multicolumn{3}{|c|}{$\begin{array}{l}\text { Daftar Induk Dokumen } \\
\text { Sebelum dievaluasi/dikaji ulang } \\
\text { (Berdasarkan Klausul pada } \\
\text { Acuan SNI } 7496: \text { 2009) }\end{array}$} & \multicolumn{3}{|c|}{$\begin{array}{l}\text { Daftar Induk Dokumen } \\
\text { Setelah dievaluasi/dikaji ulang } \\
\text { (Berdasarkan Klausul pada } \\
\text { Pedoman KNAPPP } 02: \text { 2017) }\end{array}$} \\
\hline Prosedur & $\begin{array}{c}\text { Instruksi } \\
\text { Kerja }\end{array}$ & Formulir & $\begin{array}{l}\text { Prosedur } \\
\text { (PR) }\end{array}$ & $\begin{array}{c}\text { Instruksi Kerja } \\
\text { (IK) }\end{array}$ & $\begin{array}{l}\text { Formulir } \\
\text { (FR) }\end{array}$ \\
\hline \begin{tabular}{|l|} 
PR.9.4 \\
SOP Pelaporan
\end{tabular} & - & $\begin{array}{l}\text { Formulir laporan } \\
\text { kegiatan, } \\
\text { pelaksanaan } \\
\text { pengolahan } \\
\text { bahan pustaka }\end{array}$ & & $\begin{array}{l}\text { IK. 5.9.1.9 } \\
\text { Penyusunan Laporan } \\
\text { Tahunan }\end{array}$ & $\begin{array}{l}\text { FR. 5.9.1.9.1 } \\
\text { Logbook Kegiatan } \\
\text { Harian }\end{array}$ \\
\hline \multirow[t]{2}{*}{$\begin{array}{l}\text { PR.10.9 } \\
\text { SOP Indeks } \\
\text { Kepuasan } \\
\text { Pengguna }\end{array}$} & - & $\begin{array}{l}\text { Formulir } \\
\text { evaluasi layanan } \\
\text { perpustakaan, } \\
\text { pengolahan data } \\
\text { evaluasi }\end{array}$ & & $\begin{array}{l}\text { IK.5.9.1.10 } \\
\text { Penyusunan Indeks } \\
\text { Kepuasan Pemustaka } \\
\text { (IKP) }\end{array}$ & $\begin{array}{l}\text { FR. 5.9.1.10.1 } \\
\text { Kuesioner } \\
\text { FR. 5.9.1.10.2 } \\
\text { Perhitungan Nilai IKP }\end{array}$ \\
\hline & & & & $\begin{array}{l}\text { IK.5.9.1.11 } \\
\text { Pengembangan } \\
\text { Sistem } \\
\text { Kepustakawanan, } \\
\text { Pengembangan } \\
\text { Profesi, serta } \\
\text { penunjang tugas } \\
\text { pustakawan }\end{array}$ & $\begin{array}{l}\text { FR.5.9.1.11.1 } \\
\text { Laporan Kegiatan }\end{array}$ \\
\hline \begin{tabular}{|l|} 
PR.8.3 \\
SOP \\
Pengembangan \\
Sumber Daya \\
Manusia
\end{tabular} & - & $\begin{array}{l}\text { Formulir daftar } \\
\text { riwayat hidup, } \\
\text { evaluasi personel, } \\
\text { kebutuhan } \\
\text { pelatihan }\end{array}$ & & & \\
\hline
\end{tabular}

